\title{
Kedudukan Kepala Desa Dalam Tindak Pidana Korupsi Menurut Undang-Undang Nomor 31 Tahun 1999 Jo Undang-Undang Nomor 20 Tahun 2001 Tentang Pemberantasan Tindak Pindana Korupsi
}

\author{
Syahban $^{1}$, Hotma P. Sibuea², Ika Dewi Sartika Saimima ${ }^{3}$ \\ ${ }^{123}$ Fakultas Hukum, Universitas Bhayangkara Jakarta Raya \\ Email: syahbansiregarshsiregar1873@gmail.com
}

Received : 17 Sep 2021 | Revised : 26 Oct 2021 | Accepted : 22 Nop 2021 | Published : 9 Dec 2021

\begin{abstract}
The position of the Village Head as a legal subject in law number 31 of 199 in conjunction with law number 20 of 2001 regarding corruption is not found. In this law, the legal subjects regulated in Article 1 include corporations, state administrators, civil servants and individuals. The legal vacuum in the criminal act of corruption is certainly a problem, if the village head collides with Articles 5, 11, 12 and 12 B. The problem in this research is about; Village heads have legal status as civil servants or state administrators. The ideal legal status of the Village Head in the context of the corruption law? The purpose of this study was to investigate whether the village head could be categorized as a civil servant or state administrator as referred to in law number 31 of 1999 jo law number 20 of 2001 concerning the eradication of corruption. Second, to find out the ideal legal status of the village head in law number 31 of 1999 in conjunction with law number 20 of 2001 concerning the eradication of corruption. The research method used in this research is the normative juridical research method. This study shows the following results. First, the position of the Village Head cannot be categorized as having the legal status of a Civil Servant or State Administrator as referred to in law number 31 of 1999 in conjunction with law number 20 of 2001 concerning the eradication of criminal acts of corruption. Second, the ideal legal status of the village head in relation to law number 31 of 1999 in conjunction with law number 20 of 2001 concerning the eradication of corruption is as state administrator. Suggestions that can be conveyed are as follows. First, law number 31 of 1999 in conjunction with law number 20 of 2001 concerning the eradication of corruption does not explain the legal position of the village head, whether as a civil servant or state administrator. So, to reinforce the legal position of the village head, revisions or changes need to be made. Second, in the revision or amendment of law number 31 of 1999 in conjunction with law number 20 of 2001 concerning the eradication of corruption, it is necessary to add or insert one paragraph regulating the legal status of the village head, namely as state administrator.
\end{abstract}

Keywords: Corruption Law, Legal Subjects, Legal Status, Civil Servants, State Administrators, Village Heads.

\begin{abstract}
ABSTRAK
Kedudukan Kepala Desa sebagai subjek hukum dalam undang-undang nomor 31 tahun 199 jo undang-undang nomor 20 tahun 2001 tentang tindak pidana korupsi tidak ditemukan. Dalam
\end{abstract}


undang-undang tersebut subjek hukum diatur dalam Pasal 1, meliputi, korporasi, penyelenggara negara, pegawai negeri sipil dan orang perseorangan. Kekosongan hukum dalam undang-undang tindak pidana korupsi tentu menjadi persoalan, jika kepala desa berbenturan dengan Pasal 5, 11, 12 dan 12 B. Permasalahan dalam penelitian ini adalah tentang; Kepala Desa memiliki status hukum sebagai pegawai negeri sipil atau penyelenggara negara. Status hukum Kepala Desa yang ideal dalam konteks undang-undang tindak pidana korupsi? Tujuan penelitian ini untuk Meneliti apakah kepala desa dapat dikategorikan sebagai pegawai negeri atau penyelenggara negara seperti dimaksud dalam undang-undang nomor 31 tahun 1999 jo undang-undang nomor 20 tahun 2001 tentang pemberantasan tindak pidana korupsi. Kedua, untuk mengetahui status hukum yang ideal kepala desa dalam undang-undang nomor 31 tahun 1999 jo undang-undang nomor 20 tahun 2001 tentang pemberantasana tindak pidana korupsi. Metode penelitian yang dipergunakan dalam penelitian ini adalah metoda penelitian yuridis normatif. Penelitian ini menunjukkan hasil sebagai berikut. Pertama, kedudukan Kepala Desa tidak dapat dikategorikan memiliki status hukum Pegawai Negeri atau Penyelenggara Negara seperti dimaksud dalam undang-undang nomor 31 tahun 1999 jo undang-undang nomor 20 tahun 2001 tentang pemberantasan tindak pidana korupsi. Kedua, status hukum kepala desa yang ideal dalam hubungannya dengan undang-undang nomor 31 tahun 1999 jo undang-undang nomor 20 tahun 2001 tentang pemberantasan tindak pidana korupsi adalah sebagai penyelenggara negara. Saran yang dapat disampaikan sebagai berikut. Pertama, undang-undang nomor 31 tahun 1999 jo undang-undang nomor 20 tahun 2001 tentang pemberantasan tindak pidana korupsi tidak menjelaskan kedudukan hukum kepala desa, apakah sebagai pegawai negeri atau penyelenggara negara. Maka, untuk mempertegas kedudukan hukum kepala desa tersebut perlu dilakukan revisi atau perubahan. Kedua, dalam revisi atau perubahan undang-undang nomor 31 tahun 1999 jo undang-undang nomor 20 tahun 2001 tentang pemberantasan tindak pidana korupsi perlu ditambah atau disisipkan satu ayat yang mengatur status kedudukan hukum kepala desa, yaitu sebagai penyelenggara negara.

Kata Kunci: Undang-Undang Tindak Pidana Korupsi, Subjek Hukum, Status Hukum, Pegawai Negeri, Penyelenggara Negara, Kepala Desa

\section{PENDAHULUAN}

Pasal 1 ayat (3) Undang-Undang Dasar Negara Republik Indonesia Tahun 1945 (UUD NRI Tahun 1945) amandemen ketiga menyebutkan "Negara Indonesia adalah negara hukum". ${ }^{1}$ Konsekuensi dari pasal tersebut mengisyaratkan bahwa; seluruh elemen masyarakat dan seluruh elemen unsur penyelenggara Negara dan/atau penyelenggara Pemerintahan harus menjujung tinggi serta patuh terhadap peraturan perundangundangan atau norma-norma hukum yang sudah disepakati bersama melalui Pembentuk Undang-undang yang telah diberikan kewenangan untuk Pembentukan tersebut. Negara Hukum ialah negara yang berdiri di atas hukum yang menjamin keadilan kepada warga negaranya. ${ }^{2}$ Sebagai negara hukum, segala aspek kehidupan dalam bidang kemasyarakatan, kebangsaan, dan kenegaraan termasuk pemerintahan dan bidang penegakan hukum harus dilaksanakan berdasarkan atas norma-norma hukum dan Peraturan perundang-undangan yang telah disepakati melalui pejabat pembentuk undang-undang tersebut.

Sebagai suatu Negara yang berdasarkan hukum, selain hukum dijadikan sebagai pengatur tatanan kehidupan dalam bermasyarakat, berbangsa dan bernegara agar tercapai sebuah ketertiban didalam kehidupan bermasyarakat, berbangsa dan

${ }^{1}$ Republik Indonesia Undang-Undang Dasar 1945.

${ }^{2}$ Moh.Kusnardi dan Harmaily Ibrahim, Penghantar Hukum Tata negara Indonesia, (Jakarta, Fakultas Hukum Universitas Indonesia dan CV 'Sinar Bakti”, hlm. 153. 
bernegara. Hukum juga dijadikan sebagai alat untuk mencapai tujuan negara, yakni kesejahteraan bagi seluruh masyarakat.

Untuk mencapai sebuah kesejahteraan masyarakat disebuah negara lazimnya harus ada sebuah norma-norama hukum, peraturan perundang-undangan atau prodak hukum yang mengatur pelaksanaan terhadap pelaksana/penyelenggara negara tersebut, termasuk norma-norma hukum, peraturan perundang-undangan atau prodak hukum yang memberikan sebuah sanksi bagi pelaksana/penyelenggara yang melakukan pelanggaaran terhadap kewajiban-nya.

Dalam kaitannya dengan negara hukum, asas legalitas menjadi salah satu elemen (unsur) penting dalam kehidupan bernegara dan praktik penyelenggaraan negara. Di kemudian hari, asas legalitas berkembang menjadi salah satu soko guru (tiang penopang) negara hukum. ${ }^{3}$ Asas legalitas mengandung ajaran, semua perbuatan atau tindakan pemerintah (penyelenggara negara) harus didasarkan atau berpedoman pada ketentuan hukum yang sudah ada sebelum perbuatan atau tindakaan itu dilakukan. ${ }^{4}$

Fungsi utama asas legalitas sebagai elemen (unsur) negara hukum diantaranya; (1). Fungsi pembatasan kekuasaan pemerintah (penguasa atau penyelenggara negara) dan (2) instrumen yang berfungsi melindungi hak-hak warga negara dan hak asasi manusia. ${ }^{5}$ Kedua fungsi asas legalitas tersebut berkaitan erat satu sama lain.

Pembatasan kekuasaan pemerintah telah diatur secara jelas dalam setiap jenjang (horizontal dan vertikal) Pusat dan Daerah. Pembatasan kekuasaan antara Pemerintah Pusat dan Pemerintah Daerah tercermin dalam Undang-undang Nomor 23 Tahun 2014 tentang Pemerintahan Daerah. Selain daerah-daerah otonom provinsi, kabupaten/kota, masih ada satuan pemerintahan yang lebih kecil yang kedudukannya di bawah kabupaten/kota satuan pemerintahan tersebut adalah desa. Namun, eksistensi pemerintahan desa sebagai bagian dari susunan pemerintahan Indonesia tidak diatur atau disebut dalam konstitusi. Eksistensi Pemerintahan Desa diatur Undang-undang Nomor 23 Tahun 2014 tentang Pemerintah Daerah. ${ }^{6}$

Kedudukan desa di bawah kabupaten/kota adalah bukti desa sebagai bagian pemerintahan kabupaten/kota. Desa adalah satuan pemerintahan yang bersifat otonom sama seperti provinsi, kabupaten/kota. Akan tetapi, karakteristik otonominya berbeda dari otonomi pemerintahan provinsi, kabupaten/kota. otonomi provinsi, kabupaten/kota berasal dan bersumber dari wewenang pemerintah pusat. Wewenang pemerintah pusat mengalir dari atas ke bawah sebagai bentuk pelimpahan wewenang kepada daerah-daerah otonom. Akan tetapi, Desa bertumbuh dan berkembang sebagai satuan pemerintahan otonom sejak dahulu.

Peranan penting Desa atau Kepala Desa dalam mewujudkan cita-cita negara (untuk mensejahterakan rakyat) terlihat dari besarnya Anggaran Negara yang diberikan untuk Desa/Kepala Desa dalam kurun waktu tahun 2015-2020 atau pasca terbentuknya Undang-undang nomor. 6 tahun 2014 tentang desa.

\footnotetext{
${ }^{3}$ Hotma P. Sibuea dan Asmak ul Hosnah, Sendi-Sendi Hukum Konstitusional, Problematika Wewenang organ Negara Dalam Penetapan Kerugian Keuangan Negara Dalam TIndak Pidana Korupsi, (Jakarta, Rajawali Pers, 2020), hlm. 47

${ }^{4}$ Bagir Manan, Beberapa Masalah Hukum Tata Negara Indonesia, (Bandung, Alumni, 1997), hlm.103-104.

${ }^{5}$ Hotma P. Sibuea, Op.Cit, hlm. 49.

6 Pasal 371 ayat (1) UU Nomor 23 Tahun 2014 mengatur sebagai berikut "Dalam daerah Kabupaten/Kota dapat dibentuk desa."
} 
Dalam melaksanakan perannya, Kepala Desa tidak selalu mampu melaksanakan tugas, wewenang, hak dan kewajibannya dengan baik. Sebagai contoh, seorang penjabat Kepala Desa didakwa melakukan tindak pidana korupsi berdasarkan Surat Dakwaan Jaksa Penuntut Umum No. Reg. Perkara: PDS-04/BGR/Ft.1/07/2020. Dalam register nomor perkara tersebut, Jaksa Penuntut Umum mendakwa Kepala Desa dengan dakwaan sebagai berikut. Pertama, dalam dakwaan kesatu, melanggar Pasal 12 huruf A UU RI Nomor 20 Tahun 2011 tentang Perubahan atas UU Nomor 31 Tahun 1999 tentang Pemberantasan Tindak Pidana Korupsi Jo Pasal 65 ayat 1 (satu) KUHP. Dakwaan kedua, didakwa melanggar Pasal 12 huruf B UU RI Nomor 20 Tahun 2011 tentang Perubahan atas UU Nomor 31 Tahun 1999 tentang Pemberantasan Tindak Pidana Korupsi Jo Pasal 65 ayat 1 (satu) Kitab Undang-undang Hukum Pidana (KUHP). Dakwaan ketiga, melanggar Pasal 11 UU RI Nomor 20 Tahun 2011 tentang Perubahan atas UU Nomor 31 Tahun 1999 tentang Pemberantasan Tindak Pidana Korupsi Jo Pasal 65 ayat 1 (satu) Kitab Undang-undang Hukum Pidana (KUHP)

Bagaimana dengan status hukum kepala desa, apakah kepala desa termasuk kategori "pegawai negeri sipil" atau "penyelengara negara" seperti dimaksud Pasal 5, Pasal 11, Pasal 12 dan Pasal 12 B UU Nomor 20 Tahun 2001. Berbagai undang-undang yang disebut di atas tidak mengatur status hukum penjabat kepala desa sebagai "pegawai negeri sipil" atau "penyelenggara negara." Sebagai akibatnya, status hukum penjabat Kepala Desa sebagai subjek yang didakwa melakukan tindak pidana korupsi Pasal 5, Pasal 11, Pasal 12 dan Pasal 12 B UU Nomor 20 Tahun 2001 yang memiliki elemen (unsur) "pegawai negeri" atau "penyelenggara negara" tidak dapat diketahui berdasarkan berbagai rundang-undang yang disebut di atas. Ketiadaan peraturan perundang-undangan yang mengatur status hukum kepala desa sebagai "pegawai negeri sipil" atau "penyelenggara negara" mencerminkan kekosongan undang-undang (wetvacuuum). Kekosongan undang-undang (wetvacuum) adalah kondisi yang tidak ideal yang menunjukkan kelemahan peraturan perundang-undangan sebagai kaidah yang mengatur tingkah laku anggota masyarakat. Pedoman bertingkah laku bermanfaat untuk menentukan perbuatan yang tidak boleh dilakukan, subjek yang harus bertanggung jawab dalam suatu tindakan atau peristiwa dan lain-lain.

Sudah barang tentu, kekosongan undang-undang berpotensi menimbulkan kekeliruan dalam praktik peradilan tindak pidana korupsi karena ketidakjelasan status hukum penjabat Kepala Desa yang didakwa melakukan tindak pidana korupsi menurut Pasal 5 atau Pasal 11, Pasal 12 dan Pasal 12B UU Nomor 20 Tahun 2001 termasuk kategori "pegawai negeri sipil" atau "penyelenggara negara". Penyidik, Jaksa Penuntut Umum, dan Hakim mengalami kesulitan menetapkan status hukum pejabat kepala desa yang didakwa melakukan tindak pidana korupsi seperti dikemukakan di atas dalam konteks penegakan hukum dan parktik peradilan tindak pidana korupsi.

Kesulitan tersebut berpotensi menimbulkan kekeliruan dan kesalahan penegakan hukum dan praktik peradilan tindak pidana korupsi. Kondisi demikian terjadi jika penyidik dan jaksa penuntut umum melakukan kesalahan menetapkan status hukum kepala desa termasuk kategori "pegawai negeri" atau "penyelenggara negara". Kekeliruan dalam penetapan status hukum kepala desa sebagai tersangka, terdakwa atau terpidana terjadi karena tindakan penegak hukum yang tidak cermat dan sewenang-wenang. Tindakan demikian akan mengakibatkan seorang penjabat kepala desa mengalami penderitaan dan kerugian material maupun immateril sebagai akibat kekeliruan penegak hukum menetapkan status hukum kepala desa. Untuk mencegah potensi kekeliruan dalam penegakan hukum dan praktik peradilan tindak pidana korupsi. Penelitian tentang status hukum penjabat Kepala Desa sebagai "pegawai negeri sipil" atau "penyelenggara negara" dalam konteks tindak pidana korupsi 
berdasar atas pasal-pasal yang dikemukakan di atas perlu dilakukan penelitian terkait status Kepala Desa sebagai subjek hukum dalam Undang-Undang Nomor. 20 Tahun 2001 Tentang Pemberantasan Tindak Pidana Korupsi.

Berdasarkan latar belakang di atas maka rumusan masalah yang akan dikemukakan adalah sebagai berikut;

1. Apakah Kepala Desa memiliki status hukum sebagai pegawai negeri sipil atau penyelenggara negara seperti dimaksud Pasal 5, 11, 12 dan $12 \mathrm{~B}$ undang-undang Nomor 31 Tahun 1999 jo undang-undang nomor 20 tahun 2001 tentang pemberantasan tindak pidana korupsi?

2. Bagaimana status hukum Kepala Desa yang ideal dalam konteks undangundang nomor 20 tahun 2001 tentang pemberantasan tindak pidana korupsi?

Penelitian ini dilakukan dengan metoda penelitian yuridis normatif. Penelitian hukum normatif merupakan penelitian kepustakaan yaitu penelitian terhadap data sekunder. ${ }^{7}$ Dalam penelitian ini objek yang diteliti adalah kaidah kaidah hukum, teoriteori hukum dan asas-asas hukum, sehingga metoda penelitiaan yang dipergunakan adalah metoda penelitian hukum normatif. ${ }^{8}$ Sebagai penelitian hukum dengan metoda penelitian yuridis normatif, pendekatan penelitian yang digunakan adalah pendekatan perundang-undangan (statute opproach) dan pendekatan konseptual (conceptual opproach).

Data penelitian hukum yang digunakan adalah data sekunder dalam bentuk bahan hukum primer, bahan hukum skunder dan bahan hukum tersier. Bahan hukum primer adalah norma-norma hukum positif (undang-undang) yang ditetapkan dan ditegakkan oleh negara dengan kekuasaan untuk melaksanakan keberlakukan normanorma hukum itu. Contohnya seperti Undang-Undang Dasar 1945, undang-undang atau peraturan perundangan, peraturan pemerintah, putusan mahkamah konsitusi dan lain-lain. ${ }^{9}$ Bahan hukum skunder adalah bahan hukum yang meliputi buku-buku ilmiah dibidang hukum yang mengandung doktrin-doktrin. Sebagai penelitian hukum dengan objek kaidah-kaidah hukum,pemahaman terhadap kaidah hukum dilakukan dengan cara menggunakan sarana penafsiran. Misalnya buku dan jurnal ilmiah yang berisi pendapat para pakar hukum. ${ }^{10}$ Bahan hukum tersier adalah bahan hukum yang memiliki kekuatan mengikat atas dasar kesepakatan sekelompok masyarakat berkaitan dengan suatu hal tertentu. Contohnya yaitu Kamus Bahasa Indonesia, Kamus Hukum, dan lain-lain.

\section{PEMBAHASAN}

\section{A. Krakteristik Pemerintahan Desa Menurut Peraturan Perundang-Undangan.}

Pasal 18B UUD NRI 1945 menjadi sebuah dasar hukum dalam konsitusi Negara Kesatuan Republik Indonesia untuk mengakui keberadaan masyarakat hukum desa yang ada di Indonesia untuk menyelenggarakan pemerintahannya sesuai dengan otonomi yang di miliki. Jika otonomi desa dijadikan dasar untuk melakukan penyelenggaraan pemerintahan desa berdasarkan otonom asli. Dapat diartikan bahwa

\footnotetext{
${ }^{7}$ Hotma P. Sibuea, Metoda Penelitian Hukum, Jakarta. Krakataw Book, 2007. hlm. 72.

${ }^{8}$ Roni Hanintijo Soemitro.,Metoda Penelitian Hukum dan Jumetri,Jakarta,Ghalia Indonesia, 1999.hlm.10

${ }^{9}$ Ibid.,hlm.142

${ }^{10}$ Burhan Ashofa,Metode Penelitian Hukum,Jakarta: Rineka Cipta,1996,hlm.103
} 
desa dapat mengatur dan mengurus rumah tangganya sendiri sesuai dengan kearifan dan kapasitas lokal, tanpa intervensi dan tanggungjawab dari negara.

Pemberian otonomi kepada daerah, bukanlah semata-mata persolan sistem dan cara penyelenggaraan administrasi pemerintahan. Otonomi merupakan realisasi dari pengakuan, bahwa kepentingan dan kehendak rakyatlah satu-satu sumber untuk menentukan sistem dan jalannya pemerintahan negara. Dengan demikian otonomi daerah adalah bagian keseluruhan dari usaha mewujudkan kedaulatan rakyat dalam pemerintahan. ${ }^{11}$ Sedangkan dalam Undang-undang Nomor 22 Tahun 1999 yang telah diganti dengan Undang-Undang Nomor 32 Tahun 2004 tentang Pemerintahan Daerah. Menurut Bagir Manan, ketentuan ini memberikan gambaran bahwa otonomi daerah itu merupakan wewenang dari daerah. ${ }^{12}$

Dalam pencapaian tujuan otonomi daerah harus diperhatikan beberapa unsur yang amat penting. Unsur-unsur tersebut menurut Syaukani, antara lain memantapkan kelembagaan, peningkatan kemampuan aparatur pemerintah daerah, dan kemampuan finansial (keuangan) daerah untuk membiayai pembangunan. Oleh karena itu, pemerintah daerah dituntut dapat memperbaiki dan mengembangkan unsur-unsur itu sehingga mampu menangani berbagai persoalan yang mungkin terjadi dalam penyelenggaraan otonomi daerah. ${ }^{13}$

Semangat Undang-Undang Nomor 23 Tahun 2014 tentang Pemerintahan Daerah yang meletakan posisi desa yang berada di bawah Kabupaten tidak koheren dan konkruen dengan nafas lain dalam Undang- Undang Nomor 23 Tahun 2014 yang justru mengakui dan menghormati kewenangan asli yang berasal dari hak asal-usul. Pengakuan pada kewenangan asal-usul ini menunjukkan bahwa Undang-Undang Nomor 23 Tahun 2014 menganut prinsip pengakuan (rekognisi). Kosekuensi dari pengakuan atas otonomi asli adalah "Desa memiliki hak mengatur dan mengurus rumah tangganya sendiri berdasarkan asal-usul dan adat istiadat setempat (self governing community), dan bukan merupakan kewenangan yang diserahkan pemerintahan atasan pada desa".

Penjelasan Peraturan Pemerintah Nomor 72 Tahun 2005 tentang Desa, menyatakan;

"Otonomi asli, memiliki makna bahwa kewenangan pemerintahan desa dalam mengatur dan mengurus masyarakat setempat didasarkan pada hak asal usul dan nilai-nilai sosial budaya yang terdapat pada masyarakat setempat namun harus diselenggarakan dalam perspektif adiminstrasi pemerintahan negara yang selalu mengikuti perkembangan zaman”.

Pasal 1 ayat 1,2 dan 3 Undang-undang nomor 6 tahun 2014 tentang Desa menyebutkan (1). Desa adalah desa dan desa adat atau yang disebut dengan nama lain, selanjutnya disebut Desa, adalah kesatuan masyarakat hukum yang memiliki batas wilayah yang berwenang untuk mengatur dan mengurus urusan pemerintahan, kepentingan masyarakat setempat berdasarkan prakarsa masyarakat, hak asal usul, dan/atau hak tradisional yang diakui dan dihormati dalam sistem pemerintahan Negara Kesatuan Republik Indonesia. (2). Pemerintahan Desa adalah penyelenggaraan urusan

\footnotetext{
${ }^{11}$ Ibid, hlm.22

${ }^{12}$ Bagir Manan, Fungsi dan Materi Peraturan Perundang-Undangan, Makalah, disamapaikan pada Penataran Dosen Pendidikan dan Latihan Kemahiran Hukum BKS-PTN Bidang Hukum SeWilayah Barat, Fakultas Hukum Universitas Lampung, Bandar Lampung, tanggal 11 November 1994, hlm. 2.

${ }^{13}$ Syaukani, Menatap Harapan Masa Depan Otonomi Daerah, Gerbang Dayaku, Kaltim, 2001, hlm. 179.
} 
pemerintahan dan kepentingan masyarakat setempat dalam sistem pemerintahan Negara Kesatuan Republik Indonesia. (3) Pemerintahan Desa adalah Kepala Desa atau yang disebut dengan nama lain dibantu prangkat Desa sebgai unsur penyelenggara Pemerintahan Desa.

Sedangkan Pasal 4 Undang-undang nomor 6 tahun 2014 Tentang Desa menyebutkan Pengaturan Desa bertujuan untuk:

a. Memberikan pengakuan dan penghormatan atas Desa yang sudah ada dengan keberagamannya sebelum dan sesudah terbentuknya Negara Kesatuan Republik Indonesia.

b. Memberikan kejelasan status dan kepastian hukum atas Desa dalam sistem ketatanegaraan Republik Indonesia dmi mewujudkan keadilan bagi seluruh rakyat indonesia.

c. Melestarikan dan memajukan adat, tradisi, dan budaya masyarakat Desa.

d. Mendorong prakarsa, gerakan, dan partisipasi masyarakat Desa untuk pengembangan potensi dan Aset Desa guna kesejahteraan bersama.

e. Membentuk Pemerintahan Desa yang profesional, efesien dan efektif, terbuka, serta bertanggung jawab.

f. Meningkatkan pelayanan publik bagi warga masyarakat Desa guna mempercepat perwujudan kesejahteraan umum.

g. Meningkatkan ketahanan sosial budaya masyarakat Desa guna mewujudkan masyarakat Desa yang mampu memelihara kesatuan sosial sebagai bagian dari ketahanan nasional.

h. Memajukan perekonomian masyarakat Desa serta mengatasi kesenjangan pembangunan nasional; dan

i. Memperkuat masyarakat Desa sebagai subjek pembangunan.

\section{B. Kedudukan Kepala Desa Menurut Undang-Undang Desa.}

Secara etimologi, Desa berasal dari bahasa sansekerta, deca yang berarti tanah air, tanah asal atau tanah kelahiran. Menurut Kamus Bahasa Indonesia, ${ }^{14}$ desa adalah satu kesatuan wilayah yang dihuni oleh sejumlah keluarga yang mempunyai sitem pemerintahan sendiri, dipimpin oleh seorang kepala desa atau dapat juga disebut desa merupakan kelompok rumah luar kota yang merupakan kesatuan.

Desa atau sebutan lainnya, sebagai sebuah entitas budaya, ${ }^{15}$ Desa adalah kesatuan masyarakat hukum yang mempunyai susunan asli berdasarkan hak asal-usul yang bersifat istimewa. Landasan pemikiran dalam Pemerintahan Desa adalah keanekaragaman, partisipasi, otonomi asli, demokratisasi dan pemberdayaan masyaraka. ${ }^{16}$ Desa memiliki batas-batas wilayah tertentu dan memiliki kekuasaan hukum. ${ }^{17}$ Sementara Pasal 1 angka 12 undang-undang nomor 23 tahun 2014 tentang pemerintah daerah, menyebutkan Daerah Otonom yang selanjutnya disebut Daerah adalah kesatuan masyarakat hukum yang mempunyai batas-batas wilayah yang berwenang mengatur dan mengurus Urusan Pemerintahan dan kepentingan

\footnotetext{
${ }^{14}$ Kamus Besar Bahasa Indonesia, Bitra Indonesia, Medan. 2013, hlm. 2

${ }^{15}$ R. Bintarto, Dalam Intraksi Desa Kota dan Permasalahannya, Jakarta: Ghalia Indoneisa, hlm. 1989, hlm. 35

${ }^{16}$ H.A.W Widjaja, Otonomi Desa Merupakon Otonomi yang Asli, Jakarta: Raja Grafindo persada, 2003, hal. 3

${ }^{17}$ Sugiman, Op.Cit. hlm. 85
} 
masyarakat setempat menurut prakarsa sendiri berdasarkan aspirasi masyarakat dalam sistem Negara Kesatuan Republik Indonesia.

Otonomi desa merupakan otonomi asli, bulat, dan utuh serta bukan merupakan pemberian dari pemerintah. Sebaliknya pemerintah berkewajiban rnenghormati otonomi asli yang dimiliki oleh desa tersebut. Sebagai kesatuan masyarakat hukum yang mempunyai susunan asli berdasarkan hak istimewa, desa dapat melakukan perbuatan hukum baik hukum publik maupun hukum perdata, memiliki kekayaan, harta benda serta dapat dituntut dan menuntut di muka pengadilan. ${ }^{18}$ Otonomi yang dimiliki oleh desa berbeda dengan otonomi yang dimiliki oleh provinsi maupun kabupaten/kota. Otonomi yang dimiliki oleh desa didasarkan pada asal-usul dan adat istiadatnya, bukan berdasarkan penyerahan wewenang dari Pemerintah. ${ }^{19}$ Namun demikian, dalam melaksanakan hak, kewenangan dan kebebasan dalam penyelenggaraan otonomi, desa harus tetap menjunjung nilai-nilai tanggung jawab terhadap Negara Kesatuan Republik Indonesia dengan menekankan bahwa desa adalah bagian yang tidak terpisahkan dari bangsa dan negara Indonesia.

Kepala desa bertugas menyelenggarakan pemerintahan desa, melaksanakan pembangunan desa, pembinaan kemasyarakatan desa, dan pemberdayaan masyarakat desa. Dalam melaksanakan tugas tersebut, kepala desa berwenang ; (a) memimpin penyelenggaraan pemerintahan desa, (b) mengangkat dan memberhentikan perangkat desa, (c) memegang kekuasaan pengelolaan keuangan dan aset desa, (d) menetapkan peraturan desa, (e) menetapkan Anggaran Pendapatan dan Belanja Desa, (f) membina kehidupan masyarakat desa, (g) membina ketentraman dan ketertiban masyarakat desa, (h) membinan dan meningkatkan perekonomian desa serta mengintegrasikannya agar mencapai perekonomian skala peoduktif untuk sebesar-besarnya kemakmuran masyarakat desa, (i) mengembangkan sumber pendapatan desa, (j) mengusulkan dan menerima pelimpahan sebagian kekayaan negara guna meningkatkan kesejahteraan masyarakat desa, (k) mengembangkan kehidupan sosial budaya masyarakat desa, (l) memanfaatkan teknologi tepat guna, $(\mathrm{m})$ mengoordinasikan pembangunan desa secara partisipatif, (n) mewakili desa di dalam dan diluar pengadilan atau menunjuk kuasa hukum untuk mewakilinya sesuai dengan ketentuan peraturan perundang-undangan; dan, (o) melaksanakan wewenang lain yang sesuai dengan ketentuan peraturan perundang-undangan.

Sebagai kepala pemerintahan desa, kepala desa bertugas menyelenggarakan pemerintahan desa, melaksanakan pembangunan dan pemberdayaan masyarakat. Jika merujuk pada Peraturan Menteri Dalam Negeri Nomor 84 Tahun 2015 Tentang Susunan Organisasi dan Tata Kerja (SOT) Pemerintahan Desa, untuk melaksanakan tugas kepala desa tersebut kepala desa memiliki fungsi sebagai berikut:

a. Menyelenggarakan pemerintahan desa, seperti tata praja pemerintahan, penetapan peraturan di desa, pembinaan masalah pertanahan, pembinaan ketahanan dan ketertiban, melakukan upaya perlindungan masyarakat, administrasi kependudukan dan penataan, serta pengelolaan wilayah.

b. Melaksanakan pembangunan, seperti pembangunan sarana prasarana perdesaan dan pembangunan bidang pendidikan dan kesehatan.

c. Pembinaan kemasyarakatan, seperti pelaksanaan hak dan kewajiban masyarakat, partisipasi masyarakat, sosial budaya masyarakat, keagamaan dan ketanagakerjaan.

${ }^{18}$ Ibid, hlm. 165

19 Ibid 
d. Pemberdayaan masyarakat, seperti tugas sosialisasi dan motivasi masyarakat di bidang budaya, ekonomi, politik, lingungan hidup, pemberdayaan keluarga, pemuda, olahraga dan karang taruna.

e. Menjaga hubungan kemitraan dengan lembaga masyarakat dan lembaga lainnya.

Dalam melaksanakan tugasnya, kepala desa mempunyai hak, kewajiban dan larangan adapun hak, kewajibannya dan larangan kepala desa dapat disampaikan sebagai berikut;

\section{Hak Kepala Desa;}

b. Mengusulkan struktur organisasi dan tata kerja pemerintah desa.

c. Mengajukan rancangan dan menetapkan peraturan desa.

d. Menerima penghasilan tetap setiap bulan, tunjangan, dan penerimaan lainnya yang sah, serta mendapat jaminana kesehatan.

e. Mendapatkan perlindungan hukum atas kebijakan yang dilaksanakan, dan;

f. Memberikan mandat pelaksanaan tugas dan kewajiban lainnya kepada perangkat desa.

\section{Kewajiban Kepala Desa;}

a. Memegang teguh dan mengamalkan Pancasila, melaksanakan UndngUndang Dasar Tahun 1945, serta mempertahankan dan memelihara keutuhan Negara Kesatuan Republik Indonesia,dan Bhineka Tunggal Ika.

b. Meningkatkan kesejahteraan masyarakat Desa.

c. Memelihara ketentraman dan ketertiban masyarakat Desa.

d. Menaati dan menegakkan peraturan perundang-undangan.

e. Melaksanakan kehidupan demokrasi dan berkeadilan gender.

f. Melaksanakan prinsip tata Pemerintahan Desa yang akuntabel, transfaran, profesional, efektif dan efesien, bersih, serta bebas dari kolusi, korupsi, dan nepotisme.

g. Menjalin kerjasama dan koordinasi dengan seluruh pemangku kepentingan di Desa.

h. Menyelenggarakan administrasi Pemerintahan Desa yang baik.

i. Mengelola Keuangan dan Aset Desa.

j. Melaksanakan urusan pemerintahan yang menjadi kewenangan Desa.

k. Menyelesaikan perselisihan masyarakat di Desa.

1. Mengembangkan perekonomian masyarakat Desa.

m. Membina dan melestarikan nilai sosial budaya masyarakat Desa.

n. Memberdayakan masyarakat dan lembaga kemasyarakatan di Desa.

o. Mengembangkan potensi sumber daya alam dan melestarikan lingkungan hidup; dan

p. Memberikan informasi kepada masyarakat.

\section{Larangan Kepala Desa ;}

a. Merugikan kepentingan umum.

b. Membuat keputusan yang menguntungkana diri sendiri,anggota keluarga, pihak lain, dan/atau golongan tertentu.

c. Menyalahgunakan wewenang, tugas, hak, dan/atau kewajibannya. 
d. Melakukan tindakan diskriminatif terhadap warga dan/atau golongan masyarakat tertentu.

e. Melakukan Kolusi, Korupsi, dan nepotisme, menerima uang, barang, dan/atau jasa dari pihak lain yang dapat mempengaruhi keputusan atau tindakan yang akan dilakukannya.

f. Menjadi pengurus partai politik.

g. Menjadi anggota dan/atau pengurus organisasi terlarang.

h. Merangkap jabatan sebagai ketua dan/atau anggota Badan Permusywaratan Desa, anggota Dewan Perwakilan Rakyat Republik Indonesia, Dewan Perwakilan Daerah Republik Inonesia, Dewan Perwakilan Rakyat Daerah Provinsi atau Dewan Perwakilan Rakyat Daerah Kabupaten/Kota, dn jabatan lain yang ditentukan dalam peraturan perundang-undangan.

i. Ikut serta dan/atau terlibat dalam kampanye pemilihan umum dan/atau pemilihan kepala daerah.

j. Melanggar sumpah janji jabatan;dan

k. Meninggalkan tugas selama 30 (tiga puluh) hari kerja berturut-turut tanpa alasan yang jelas dan tidak dapat dipertanggungjawabkan.

1) Dalam hal sanksi administratif sebagaimana dimaksud ayat (1) tidak dilaksanakan.dilakukan tindakan pemberhentian sementara dan dapat dilanjutkan dengan pemberhentian.

\section{Subjek Hukum Yang Dapat Dipidana Menurut Undang-undang Pemberantasan Tindak Pidana Korupsi.}

Subjek hukum adalah orang yang dapat dipertanggungjawabkan sebagai pelaku tindak pidana. Pasal (2) Undang-Undang Nomor 31 Tahun 1999 jo UndangUndang Nomor 20 Tahun 2001 Tentang Pemberantasan Tindak Pindana Korupsi menyebutkan bahwa; (1) setiap orang yang secara melawan hukum melakukan perbuatan memperkaya diri sendiri atau orang lain atau suatu korporasi yang dapat merugikan keuangan negara atau perekonomian negara, dipidana penjara dengan penjara seumur hidup atau pidana penjara paling singkat 4 (empat) tahun dan paling lama 20 (dua puluh) tahun dan denda paling sedikit Rp. 200.000.000., (dua ratus juta rupiah) dan paling banyak Rp. 1.000.000.000., (satu milyar rupiah). (2) dalam hal tindak pidana korupsi sebagaimana dimaksud dalam ayat (1) dilakukan dalam keadaan tertentu, pidana mati dapat dijatuhkan.

Secara historis, ketentuan pasal 2 ayat (1) tersebut berasal dari norma hukum yang terdapat dalam pasal 1 ayat (1) Undang-Undang Nomor 3 Tahun 1971 Tentang Pemberantasan Tindak Pidana Korupsi, yang kemudian diadopsi kedalam UndangUndang Nomor 31 Tahun 1999 jo Undang-Undang Nomor 20 Tahun 2001 Tentang Pemberantasan Tindak Pindana Korupsi. ${ }^{20}$ Selain Pasal 2 Pasal 3 juga norma hukumnya bersumber dari Pasal 1 ayat (1) UU Nomor 3 Tahun 1971.

Pasal 3 Undang-Undang Nomor 31 Tahun 1999 jo Undang-Undang Nomor 20 Tahun 2001 Tentang Pemberantasan Tindak Pindana Korupsi berbunyi sebagai berikut "Setiap orang yang dengan tujuan menguntukan diri sendiri atau orang lain atau suatu korporasi, menyalahgunakan kewenangan, kesempatan, atau sarana yang ada padanya karena jabatan atau kedudukan yang dapat merugikan keuangan negara atau perekonomian negara, dipidana dengan pidana seumur hidup atau pidana penjara

${ }^{20}$ http://www.hukumonline.com, Memahami Kembali Delik Formil Pada Pasal 2 dan Pasal 3 UU Tipikor. Pebruari 2017. Diakses tgl.12-05-2021, jam. 21.20 Wib. 
paling singkat 1 (satu) tahun dan paling lama 20 (dua puluh) tahun dan atau denda paling sedikit Rp. 50.000.000 (lima puluh juta rupiah) dan paling banyak Rp1.000.000.000 (satu milyar rupiah)".

Pasal 2 ayat (1) dan Pasal 3 ditujukan kepada Subjek hukum seorang pegawai negeri atau penyelengara negara yang memiliki kekuasaan, meskipun dalam UU Tipikor dan perubahannya tidak secara tegas menyatakan demikian. ${ }^{21}$ Pasal 2 ayat (1) memiliki tiga unsur, yaitu (a) dapat memperkaya diri sendiri, orang lain, atau korporasi; (b) melawan hukum; (c) merugikan keuangan atau perekonomian negara. Perbuatan yang dilarang dalam pasal tersebut adalah perbuatan yang memperkaya diri sendiri, orang lain, atau korporasi dengan menggunakan sarana melawan hukum tanpa perlu dibuktikan apakah dari perbuatannya tersebut timbul kerugian keuangan negara atau benar-benar merugikan perekonomian negara. ${ }^{22}$ Pasal 3 juga memiliki tiga unsur yaitu (a) dengan tujuan menguntungkan diri sendiri atau orang lain, atau suatu korporasi; (b) menyalahgunakan kewenangan, kesempatan atau sarana yang ada padanya karena jabatan atau kedudukan; (c) dapat merugikan keuanganatau perekonomin negara.

Dalam perakteknya, subjek hukum Pasal 2 ayat (1) UU Tipikor diterapkan kepada subjek tindak pidana korupsi dari pihak non pegawai negeri atau pihak swasta. $^{23}$ sedangkan Pasal 3 UU Tipikor diterapkan kepada subjek tindak pidana korupsi dari pihak pegawai negeri atau pejabat umum. ${ }^{24}$ Dua pasal tersebut sama-sama menjerat pelaku tindak pidana korupsi. Perbedaannya, dalam Pasal 3 pelaku bisa dijerat jika mempunyai kewenangan, sedangkan Pasal 2 setiap orang yang dimaksud dalam pasal lebih luas dan umum. ${ }^{25}$ Pihak Swasta dan korporasi hanya dapat menjadi pelaku tindak pidana korupsi apabila pihak swasta dan korporasi tersebut bertindak sebagai pemberi suap atau Aktieve Omkoping. ${ }^{26}$

Hubungan dengan Subjek Hukum dalam UU Tipikor dijelaskan dalam Pasal (1) Undang-Undang Nomor 31 Tahun 1999 Tentang Pemberantasan Tindak Pidana Korupsi sebagaimana telah diubah menjadi Undang-Undang Nomor 20 Tahun 2001 Tentang Pemberantasan Tindak Pindana Korupsi sebagai berikut; “ (1) Korporasi adalah kumpulan dan/atau kekayaan yang terorganisasi baik merupakan badan hukum maupun bukan badan hukum. Selanjutnya dalam ayat (2) dijelaskan bahwa Pegawai Negeri meliputi; (a) pegawai negeri sebagaimana dimaksud dalam undang-undang tentang kepegawaian, (b) pegawai negeri sebagaimana dimaksud dalam kitab undangundang hukum pidana, (c) orang yang menerima gaji atau upah dari keuangan negara atau daerah, (d) orang yang menerima gaji atau upah dari suatu korporasi yang menerima bantuan dari keuangan negara atau daerah; atau (e) orang yang menerima gaji atau upah dari korporasi lain yang mempergunakan modal atau fasilitas dari negara atau masyarakat. Sedangkan yang dimaksud dengan "orang" dalam ayat (3) dijelaskan "Setiap orang adalah orang perseorangan atau termasuk korporasi"27

${ }^{21}$ Ibid

22 Ibid

${ }^{23}$ Darwin Prints, Pemberantasan Tindak Pidana Korupsi, Bandung: Pt Cttraditya Bakti, 2001, hlm.29.

${ }^{24} \mathrm{Op}$-Cit

25 http://www.hukumonline.com, Sekali Lagi Pasal 2 dan Pasal 3 UU Tipikor, April, 2016. Diakses, tgl.12-05-2021, jam. 21.36 Wib.

26 http://busenees-law.bunus.ac.id, Siapa Subjek Tindak Pidana Korupsi, Februari 2017, diakses tgl, 12-05-2021, jam, 22.53

${ }^{27}$ Undang-Undang Republik Indonesia Nomor, 31 Tahun 1999 Jo Undang-Undang Republik Indonesia Nomor 31 Tahun 2001 Tentang Pemberantasan Tindak Pidana Korupsi. 
Dalam Undang-Undang Nomor 31 Tahun 1999 Jo Undang-Undang Nomor 20 Tahun 2001 Tentang Pemberantasan Tindak Pidana Korupsi terdapat beberapa pasal yang berkaitan dengan subjek hukum Pegawai Negeri atau Penyelenggara Negara yang dapat dipidana, yakni; Pasal 5, Pasal 9, Pasal 10, Pasal 11, Pasal 12, dan Pasal 12B. Pasal yang terkait dengan gratifikasi terdiri dari Pasal 5, Pasal 11 dan Pasal 12 dan Pasal 12B.

Dari uraian diatas jelas Kepala Desa bukan Pegwai Negeri, karena kepala desa tidak mendapatkan jaminan pensiun dan jaminan hari tua, bahkan untuk mendaptarkan calon kepala desa tidak dibenarkan seorang Pegawai Negeri Sipil. Dengan kata lain, jika seseorang ingin mencalonkan diri sebagai kepala desa harus terlebih dahulu mengundurkan diri/cuti dari jabatan Pegawai Negeri Sipilnya.

Sedangkan istilah penyelenggaraan negara disebut dalam pasal 1 (satu) ayat 1 (satu) Undang-Undang Nomor 28 Tahun 1999 Tentang Penyelenggaraan Negara Yang Bersih Dan Bebas Dari Korupsi Kolusi Dan Nepotisme, yang menyebutkan "penyelenggara negara adalah pejabat negara yang menjalankan fungsi eksekutif, legislatif atau yudikatif dan pejabat lain yang fungsi dan tugas pokoknya berkaitan dengan penyelenggaraan negara sesuai dengan ketentuan peraturan perundangundangan" menurut defenisi yang dikemukakan di atas " penyelenggara negara" adalah dan haruslah pejabat negara. Siapa-siapa saja yang termasuk kategori pejabat negara sebagai penyelenggara tersebut.

Pejabat negara yang dapat dikategorikan sebagai penyelenggara negara menurut Pasal 2 Undang-Undang Nomor 28 Tahun 1999 Tentang Penyelenggaraan Negara Yang Bersih Dan Bebas Dari Korupsi Kolusi Dan Nepotisme meliputi; (1) pejabat negara pada lembaga tertinggi negara, (2) pejabat negara pada lembaga tinggi negara, (3) menteri, (4) gubernur, (5) hakim, (6) pejabat negara yang lain sesuai dengan ketentuan peraturan perundang-undangan dan; (7) pejabat lain yang memiliki fungsi strategis dalam kaitannya dengan penyelenggaraan negara sesuai dengan ketentuan peraturan perundang-undangan yang berlaku.

Sedangkan yang dimaksud dengan pejabat negara lain seperti dimaksud pasal 2 ayat 6 Undang-Undang Nomor 28 Tahun 1999 dalam penjelasannya disebutkan sebagai berikut; "yang dimaksud dengan Pejabat Negara lainnya dalam ketentuan ini misalnya, Kepala Perwakilan Republik Indonesia di luar negeri yang berkedudukan sebagai Duta Besar Luar Biasa dan Berkuasa Penuh, Wakil Gubernur, dan Bupati/Walikotamadya". Sedangkan pejabat lain yang memiliki fungsi strategis sebagaimana dimaksud dalam pasal 2 ayat (7) adalah pejabat yang tugas dan wewenangnya didalam melakukan penyelenggaraan negara meliputi:

1. Direksi, Komisaris dan pejabat struktural lainnya pada Badan Usaha Milik Negara dan Badan Usaha Milik Daerah.

2. Pimpinan Bank Indonesia dan Pimpinan Badan Penyehatan Perbankan Nasional.

3. Pimpinan Perguruan Tinggi Negeri.

4. Pejabat Eselon I dan Pejabat lain yang disamakan dilingkungan sipil, militer, dan Kepolisisn Negara Republik Indonesia.

5. Jaksa

6. Penyidik

7. Panitera Pengadilan; dan

8. Pemimpin dan bendaharawan proyek 
Terkait pejabat negara yang termasuk golongan "penyelenggara negara" juga dapat ditemukan dalam undang-undang lain, yaitu undang-undang nomor 43 tahun 1999 tentang pokok-pokok kepegawaian, dalam pasal 1 (satu) ayat 4 (empat) menyebutkan "Pejabat negara adalah pimpinan dan anggota lembaga tertinggi/tinggi negara sebagaimana dimaksud dalam Undang-Undang Dasar 1945 dan pejabat negara lainnya yang ditentukan undang-undang". Kelompok (golongan) pejabat negara yang dimaksud di atas disebut atau diatur dalam Pasal 11 ayat 1 (satu) UU No. 43 Tahun 1999 yang menyebutkan sebagai berikut, pejabat negara terdiri atas;

1. Presiden dan Wakil Presiden.

2. Ketua, Wakil Ketua dan Anggota Majelis Permusyawaratan Rakyat,

3. Ketua, Wakil Ketua dan Anggota Dewan Perwakilan Rakyat,

4. Ketua, Wakil Ketua. Ketua Muda dan Hakim Agung pada Mahkamah Agung serta Ketua, Wakil Ketua dan Hakim Pada semua Badan Peradilan,

5. Ketua, Wakil Ketua dan Anggota Dewan Pertimbangan Agung,

6. Ketua, Wakil Ketua dan Anggota Badan Pemeriksa Keuangan,

7. Menteri dan jabatan yang setingkat dengan menteri,

8. Kepala Perwakilan Republik Indonesia di luar negeri yang berkedudukan sebagai Duta Besar Luar Biasa dan Berkuasa penuh,

9. Gubemur dan Wakil Gubemur.

10. Bupati/Walikota dan Wakil Bupati/Wakil Walikota dan

11. Pejabat negara lainnya yang ditentukan oleh undang-undang.

Sedangkan yang termasuk golongan pejabat negara menurut undang-undang lain, yakni undang-undang nomor 5 tahun 2014 tentang aparatur sipil negara seperti disebut dalam pasal 122 menyebutkan sebagai berikut "Pejabat Negara sebagaimana disebut dalam Pasal 121 yaitu";

1. Presiden dan Wakil Presiden,

2. Ketua, Wakil Ketua dan Anggota Majelis Permusyawaratan Rakyat,

3. Ketua. Wakil Ketua dan Anggota Dewan Perwakilan Rakyat,

4. Ketua, Wakil Ketua dan Anggota Dewan Perwakilan Daerah,

5. Ketua, Wakil Ketua, Ketua Muda dan Hakim Agung pada Mahkamah Agung serta Ketua, Wakil Ketua dan hakim pada semua badan peradilan kecuali hakim ad hoc,

6. Ketua, Wakil Ketua dan Anggota Mahkamah Konstitusi,

7. Ketua, Wakil Ketua dan Anggota Badan Pemeriksa Keuangan,

8. Ketua, Wakil Ketua dan Anggota Komisi Yudisial,

9. Ketua, Wakil Ketua dan Anggota Komisi Pemberantasan Korupsi,

10. Menteri dan Jabatan setingkat menteri,

11. Kepala Perwakilan Republik Indonesia di luar negeri yang berkedudukan sebagai Duta Besa Luar Biasa dan Berkuasa Penuh,

12. Gubemur dan Wakil Gubernur,

13. Bupati/Walikota dan Wakil Bupati/Wakil Walikota dan

14) Pejabat negara lainnya yang ditentukan oleh Undang-undang

Undang -Undang Nomor 9 Tahun 2010 Tentang Keprotokalan dalam Pasal 1 ayat (7) disebutkan bahwa pejabat negara adalah pimpinan dan anggota lembaga negara sebagaimana dimaksud dalam UUD 1945 yang secara tegas ditentukan oleh undang-undang. Sedangkan dalam Pasal 1 ayat (8) ditegaskan bahwa pejabat 
pemerintahan adalah pejabat yang menduduki jabatan tertentu dalam pemerintahan baik di pusat mapun di daerah.

Dari pernyataan-pernyataan yang telah diuraikan di atas jelas subjek-subjek hukum yang dapat diminta pertanggungjawaban pidananya, jika melanggar ketentuanketentuan yang terkandung dalam undang-undang, jika merujuk pada pasal 1 undangundang no 31 tahun 1999 sebagaimana telah diubah menjadi undang-undang nomor 20 tahun 2001 tentang pemberantasan tindak pidana korupsi, maka dapat dilihat yang menjadi subjek undang-undang tersebut adalah, korporasi, Pegawai Negeri Sipil dan orang perseorangan, sementara penyelenggara negara tidak dijelaskan. Akan tetapi, jika melihat secara keseluruhan dalam beberapa pasal, khusus pasal yang berkaitan dengan ancaman pidana, maka dapat dilihat subjek hukum yang dapat dipidana meliputi; Badan hukum, pegawai negeri sipil, penyelenggara negara dan orang perorangan.

\section{Kedudukan Kepala Desa Dalam Hubungan Undang-Undang Pemberantasan Tindak Pidana Korupsi Menurut Pasal 5,11 dan 12.}

Keberagaman karakteristik dan jenis desa, atau yang disebut nama lain tidak menjadi penghalang bagi para pendiri bangsa "founding fathers" ini untuk menjatuhkan pilihannya pada bentuk negara kesatuan. Meskipun didasari bahwa dalam suatu negara kesatuan perlu terdapat homogenitas. Tetapi Negara Kesatuan Republik Indonesia tetap memerlukan pengakuan dan jaminan terhadap keberadaan kesatuan masyarakat hukum dan kesatuan masyarakat hukum adat beserta hak tradisionalnya tersebut ${ }^{28}$

Desa adat pada prinsipnya merupakan warisan organisasi kepemerintahan masyarakat lokal yang dipelihara secara turun temurun yang tetap diakui dan diperjuangkan oleh pemimpin dan masyarakat desa adat, agar dapat berfungsi mengembangkan kesehjahteraan dan identitas sosial budaya lokal. Desa adat memiliki hak asal usul yang lebih dominan, daripada hak asal usul desa sejak desa adat itu lahir sebagai komunitas asli yang ada ditengah masyarakat.

Kepala/Desa Adat atau yang disebut dengan nama lain merupakan kepala pemerintahan desa/desa adat yang memimpin penyelenggaraan pemerintahan desa, kepala desa mempunyai peran penting dalam kedudukannya sebagai kepanjangan tangan negara yang dekat dengaan masyarakat dan sebagai pemimpin masyrakat. Dengan posisi yang demikian itu, prinsif pengatauran tentang kepala desa/desa adat dapat dikemukakan sebagai berikut;

a. Sebutan kepala desa/desa adat disesuaikan dengan sebutan lokal.

b. Kepala desa/desa adat berkedudukan sebagai kepala pemerintah desa/desa adat dan sebagai pemimpin masyarakat.

c. Kepala desa dipilih secara demokratis dan langsung oleh masyarakat setempat, kecuali bagi desa adat dapat menggunakan mekanisme lokal; dan

d. Pencalonan kepala desa dalam pemilihan langsung tidak menggunakan basis partai politik sehingga kepala desa dilarang menjadi pengurus partai politik.

\footnotetext{
${ }^{28}$ Ibid.,
} 
Mengingat kedudukan, kewenangan, dan keuangan desa yang semakin kuat, penyelenggaraan pemerintahan desa harus lebih akuntabel yang juga harus didukung dengan sistem pengawasan dan keseimbangan antara pemerintah desa dan lembaga desa. Lembaga desa, khususnya Badan Permusywaratan Desa (BPD) yang dalam kedudukannya mempunyai fungsi penting dalam menyiapkan visi dan misi yang sama dengan kepala desa sehingga BPD Desa tidak dapat menjatuhkan kepala desa yang dipilih. ${ }^{29}$ Badan Permusyawaratan Desa atau yang disebut dengan nama lain adalah lembaga yang melakukan fungsi pemerintahan yang anggotanya merupakan wakil dari penduduk desa berdasarkan keterwakilan wilayah dan ditetapkan secara demokratis. Badan Permusyawaratan Desa merupakan badan permusyawaratan di tingkat desa yang turut membahas dan menyepakati berbagai kebijakan dalam penyelenggaraan pemerintahan desa. Dalam upaya meningkatkan kinerja kelembagaan tingkat desa, memperkuat kebersamaan, serta meningkatkan partisipasi dan pemberdayaan masyarakat.

Kepala Desa dan Badan Permusyawaratan Desa membahas peraturan desa, setelah disepakati kemudian ditetapkan kepala desa menjadi kerangka hukum dan kebijakan dalam penyelenggaraan pemerintahan desa dan pembangunan desa. Penetapan peraturan desa merupakan penjabaran atas berbagai kewenangan yang dimiliki desa mengacu pada pada ketentuan peraturam perundang-undangan yang lebih tinggi. Sebagai sebuah produk hukum, peraturan desa tidak boleh bertentangan dengan peraturan yang lebih tinggi dan tidak boleh merugikan kepentingan umum. ${ }^{30}$ Peraturan desa dapat dikategorikan sebagai produk politik desa. Sebab peraturan desa diproses secara demokratis dan parsitipatif, yakni proses penyusunannya mengikutsertakan partisipasi masyarakat desa. Masyarakat mempunyai hak untuk mengusulkan atau memberikan masukan kepada kepala desa dan Badan Permusyawaratan desa dalam proses penyusunan peraturan desa tersebut.

Peraturan desa yang mengatur kewenangan desa berdasarkan hak asal usul dan kewenangan berskala lokal, pelaksanaannya di awasi oleh masyarakat dan BPD. Hal itu dimkasudkan agar pelaksanaan peraturan desa senantiasa dapat diawasi secara berkelanjutan oleh warga masyarakat setempat. Apabila terjadi pelanggaran terhadap pelaksanaan peraturan desa yang telah ditetapkan BPD berkewajiban mengingatkan dan menindaklanjuti pelanggaran sesuai dengan kewenangan yang dimiliki. Itulah salah satu fungsi pengawasan yang dimiliki Badan Permusyawaratan Desa. Selain BPD, masyarakat desa juga mempunyai hak untuk melakukan pengawasan dan evaluasi secara partisipatif terhadap pelaksanaan peraturan desa. ${ }^{31}$

Kepala desa dipilih secara langsung oleh dan dari penduduk desa warga negara Republik Indonesia yang memenuhi persyaratan dengan masa jabatan 6 (enam) tahun terhitung sejak tanggal pelantikan. Kepala desa dapat menjabat paling banyak 3 (tiga) kali masa jabatan secara berturut-turut atau tidak secara berturut-turut. Sedangkan pengisian jabatan dan masa jabatan kepala desa adat berlaku ketentuan hukum adat di desa adat tersebut, sepanjang masih hidup dan sesuai dengan perkembangan masyarakat serta prinsip Negara Kesatuan Republik Indonesia yang ditetapkan dalam Peraturan Daerah (PERDA) Kabupaten/Kota dengan berpedoman pada Peraturan pemerintah (PP). ${ }^{32}$
${ }^{29}$ Ibid
${ }^{30}$ Ibid.,
${ }^{31}$ Ibid.
32 Ibid., 
Desa mempunyai sumber pendapatan yang terdiri atas pendapatan asli desa, bagi hasil pajak daerah dan retrebusi daerah Kabupaten/Kota, bagian dari dana perimbangan keuangan pusat dan daerah yang diterima oleh Kabupaten/Kota, alokasi anggaran dari Anggaran Pendapatan dan Belanja Negara, bantuan keuangan dari Anggaran Pendapatan dan Belanja Daerah Provinsi dan Anggaran Pendapatan dan Belanja Daerah Kabupaten/Kota, serta hibah dan sumbangan yang tidak mengikat dari pihak ketiga.

Bantuan keuangan dari Anggaran Pendapatan dan Belanja Daerah untuk Desa pasca berlukanya Undang-Undang Nomor 6 Tahun 2014 Tentang Desa cukup besar, pada tahun 2015 pagu anggaran Rp. 20,76 triliun, tahun 2016 Rp. 46, 98 triliun, tahun Rp. 2017 Rp. 60,00 triliun, tahun 2018 Rp. 60,00 triliun, tahun 2019 Rp. 70,00 triliun dan tahun 2020 Rp. 71, 19 triliun. ${ }^{33}$

Bantuan keuangan dari Anggaran Pendapatan dan Belanja Daerah Provinsi dan Anggaran Pendapatan dan Belanja Daerah Kabupaten/Kota kepada desa diberikan sesuai dengan kemampuan keuangan Pemerintah Daerah yang bersangkutan. Bantuan daerah tersebut diarahkan untuk percepatan pembangunan desa. Sedangkan sumber pendapatan lainyang dapat diusahakan oleh desa berasal dari Badan Usaha Milik Desa (BUMDES), pengelolaan pasar desa, pengelolaan kawasan wisata skala desa, pengelolaan tambang mineral bukan logam dan tambang batuan dengan tidak menggunakan alat berat, serta sumber lainnya. ${ }^{34}$

Anggaran Pendapatan dan Belanja Desa dari sumber seperti telah dikemukakan di atas bertujuan untuk Pembangunan Desa, dengan sasaran meningkatkan kesejahteraan masyarakat desa dan kualitas hidup masyarakat serta penanggulangan kemiskinan melalui penyediaan pemenuhan kebutuhan dasar. Pembangunan sarana dan prasarana, pengembangan potensi ekonomi lokal, serta pemanfaatan sumber daya alam dan lingkungan secara berkelanjutan. Sebagai konsekuensinya, desa menyusun perencanaan pembangunan sesuai dengan kewenangannya dengan mengacu pada perencanaan pembangunan Kabupaten/Kota. Dokumen rencana pembangunan desa merupakan satu-satunya dokumen perencanaan di desa dan sebagai dasar penyusunan Angaran Pendapatan dan Belanja Desa.

Perencanaan pembangunan desa diselenggarakan dengan mengikutsertakan masyarakat desa melalui Musyawarah Perencanaan Pembangunan (MUSREMBANG) Desa, MUSREMBANG dilakukan untuk tujuan menetapkan prioritas, program, kegiatan dan kebutuhan Pembangunan Desa yang didanai oleh Anggaran Pendapatan dan Belanja Desa, swadaya masyarakat desa berdasarkan penilaian terhadap kebutuhan masyarakat. pembangunan desa dilaksanakan oleh pemerintah desa dan masyarakat desa dengan semangat gotong royong serta memanfaatkan kearifan lokal dan sumber daya alam desa. Pelaksanaan program sektor yang masuk ke desa diinformasikan kepada pemerintahan desa dan diintegrasikan dengan rencana pembangunan desa. Masyarakat desa berhak mendapatkan informasi dan melakukan pemantauan mengenai rencana dan pelaksanaan pembangunan desa.

Sejalan dengan tugas dan fungsi serta kewenangan kepala desa dalam mewujudkan pembangunan dan peningkatan kesejahteraan masyarakat, tidak semua kepala desa mampu menjalankan tugas, fungsi dan kewenangannya sesuai dengan ketentuan peraturan perundang-undangan yang berlaku, hal itu terlihat pada

${ }^{33}$ http://www.djkp.kemenkeu.go.id. Kebijakan Dana Desa Tahun 2021 (diakses 13-05-2021, jam. 20;46 wib)

${ }^{34}$ Op. Cit., 
banyaknya kepala desa tersangkut dengan hukum khususnya dengan Undang-Undang Tindak Pidan Korupsi. Menurut data Badan Pengelolaan perbatasan (BNPP) RI dalam kurun waktu 2015-2019 setidaknya ada 473 Kepala Desa terseret kasus korupsi. ${ }^{35}$

Beberapa contoh perkara tindak pidana korupsi kepala desa dapat dilihat dalam Putusan Nomor;29/Pid.Sus-TPK/2018/PN. Bdg. Putusan Nomor; 10/Pid.Sus /TPK/2019/PN. Tpg dan Nomor; 21/Pid.Sus-TPK/2020/PN.Bdg . ${ }^{36}$ Pada putusan nomor 21/Pid.Sus-TPK/2020/PN.Bdg. Kepala Desa Limusnunggal dinyatakan bersalah melanggar pasal 11 undang-undang nomor 31 tahun 1999 sebagaimana telah diubah dengan undang-undnag nomor 20 tahun 2001 jo pasal 65 ayat (1) KUHP. Dalam dakwaan Penuntut umum kepala desa didakwa dalam dakwaan kesatu dengan Pasal 12 hurup (a), dakwaan kedua pasal 12 hurup (b), dan dakwaan ketiga dengan pasal 11.

Undang-Undang Nomor 28 Tahun 1999 Tentang Penyelenggaraan Negara Yang Bersih Dan Bebas Dari Korupsi, Kolusi Dan Nepotisme alinea ke empat disebutkan "Tindak pidana korupsi, kolusi, dan nepotisme tersebut tidak hanya dilakukan oleh Penyelenggara Negara, antar Penyelenggara Negara, melainkan juga Penyelenggara Negara dengan pihak lain seperti keluarga kroni, dan para pengusaha, sehingga merusak sendi-sendi kehidupan bermasyarakat, berbangsa, dan bernegara, serta membahayakan eksistensi negara". ${ }^{37}$

Dalam kaitannya dengan Penyelenggaraan Negara yang bersih dan bebas dari korupsi, kolusi, dan nepotisme seperti dimaksud dalam UU No, 28 Tahun 1999 telah dibentuk undang-undang nomor 31 Tahun 1999 dan telah diubah menjadi undangundang nomor 21 tahun 2001 tentang pemberantasan tindak pidana korupsi beserta lembaga pelaksananya yakni komisi pemeberantasan tindak pidana korupsi melalui undang-undang nomor 19 tahun 2019 tentang perubahan kedua atas undang-undang nomor 30 tahun 2002 tentang komisi pemberantasan tindak pidana korupsi. Selain Kepolisian dan Kejaksaan, komisi pemberantasan tindak pidana korupsi menjadi lembaga yang cukup berperan efektif dalam pemberantasan tindak pidana korupsi di Indonesia.

Pasal 5 Undang Undang Nomor. 31 Tahun 1999 Jo Undang-Undang Nomor 20 Tahun 2001 Tentang Pemberantasan Tindak Pidana Korupsi menyebutkan “ (1) dipidana dengan pidana penjara paling singkat 1 (satu) tahun dan paling lama 5 (lima tahun dan/atau pidana denda paling sedikit Rp. 50.000.000., (lima puluh juta ruapiah) dan paling banyak Rp. 250.0000.000., (dua ratus lima puluh juta rupiah) setiap orang ; (a) memberi atau menjanjikan sesuatu kepada Pegawai negeri atau penyelenggara negara dengan maksud supaya pegawai negeri atau penyelenggara negara tersebut berbuat atau tidak berbuat sesuatu dalam jabatannya, yang bertentangan dengan kewajibannya atau; (b) memberi sesuatu kepada pegawai atau penyelenggara negara karena atau berhubungan dengan sesuatu yang bertentangan dengan kewajiban, dilakukan atau tidak dilakukan dalam jabatannya, (2) bagi pegawai negeri atau penyelenggara negara yang menerima pemberian atau janji sebagaimana dimaksud

\footnotetext{
${ }^{35}$ https://m.mediaindonesia.com., BNNP; 473 Kades Telah Terseret Korupsi Dana Desa, Februari, 2020, ( diakses, 14-05-2021, jam. 8;43; wib)

${ }^{36}$ https://putusan.3mahkamahagung.go.id., Direktori Putusan Mahkamah Agung Republik Indonesia., ( diakses 14-05-2021, jam 9,57;wib)

${ }^{37}$ Republik Indonesia, Undang-Undang Nomor 28 Tahun 1999 Tentang Penyelenggaraan Negara Yang Bersih Dan Bebas Dari Korupsi, Kolusi, Dan Nepotisme, (LN. Nomor. 75. TLN Nomor. 3851). Tahun 1999.
} 
dalam ayat (1) huruf (a) atau huruf (b), dipidana dengan pidana yang sama sebagaimana dimaksud dalam ayat (1). ${ }^{38}$ Dalam penjelasan Pasal 5 ayat (2) dijelaskan "yang dimaksud dengan penyelenggara negara dalam pasal ini adalah penyelenggara negara sebagaimana dimaksud dalam Pasal 2 undang-undang nomor 28 tahun 1999 tentang penyelenggaraan negara yang bersih dan bebas dari korupsi, kolusi, dan nepotisme. Pengertian penyelenggara negara tersebut berlaku pula untuk pasal-pasal berikutnya dalam undang ini”.

Sedangkan bunyi Pasal 11 Undang Undang Nomor. 31 Tahun 1999 Jo Undang-Undang Nomor 20 Tahun 2001 Tentang Pemberantasan Tindak Pidana Korupsi disebutkan "Dipidana penjara paling singkat 1 (satu) tahun dan paling lama 5 (lima) tahun dan atau pidana denda paling sedikit Rp. 50.000.000., (lima puluh juta rupiah) dan paling banyak Rp. 250.000.000., (dua ratus lima puluh juta rupiah) pegawai negeri atau penyelenggara negara yang menerima hadiah atau janji padahal diketahui atau patut diduga, bahwa hadiah atau janji tersebut diberikan karena kekuasaan atau kewenangan yang berhubungan dengan jabatannya, atau patut menurut pikiran orang yang memberikan hadiah atau janji tersebut ada hubungan dengan jabatannya"

Kemudian, Pasal 12 Undang Undang Nomor. 31 Tahun 1999 Jo UndangUndang Nomor 20 Tahun 2001 Tentang Pemberantasan Tindak Pidana Korupsi Menyebutkan " Dipidana dengan pidana penjara seumur hidup atau pidana penjara paling singkat 4 (empat) tahun dan paling lama 20 (dua puluh) tahun dan pidana denda paling sedikit Rp 200.000.000,00 (dua ratus juta rupiah) dan paling banyak Rp 1.000.000.000,00 (satu miliar rupiah) (a) pegawai negeri atau penyelenggara negara yang menerima hadiah atau janji, padahal diketahui atau patut diduga bahwa hadiah atau janji tersebut diberikan untuk menggerakkan agar melakukan atau tidak melakukan sesuatu dalam jabatannya, yang bertentangan dengan kewajibannya; (b) pegawai negeri atau penyelenggara negara yang menerima hadiah, padahal diketahui atau patut diduga bahwa hadiah tersebut diberikan sebagai akibat atau disebabkan karena telah melakukan atau tidak melakukan sesuatu dalam jabatannya yang bertentangan dengan kewajibannya;

Jika melihat penjelasan "penyelenggara negara" dalam penjelasan Pasal 5 ayat (2) UU Tipikor adalah penyelenggara negara sebagaimana dimaksud dalam Pasal 2 UU No. 28 Tahun 1999 tentang Penyelenggaraan Negara yang Bersih dan Bebas Dari Korupsi, Kolusi, dan Nepotisme, yaitu:

1. Pejabat Negara pada Lembaga Tertinggi Negara;

2. Pejabat Negara pada Lembaga Tinggi Negara;

3. Menteri;

4. Gubernur;

5. Hakim;

6. Pejabat negara yang lain sesuai dengan ketentuan peraturan perundangundangan yang berlaku; dan

7. Pejabat lain yang memiliki fungsi strategis dalam kaitannya dengan penyelenggara negara sesuai dengan ketentuan peraturan perundangundangan yang berlaku.

${ }^{38}$ Republik Indonesia, Pasal 5 Undang-Undang Nomor 20 Tahun 2001, Tentang Perubahan Atas Undang-Undang Nomor 31 Tahun 2001 Tentang Pemberantasan Tindak Pidana Korupsi., (LN. No. 134. TLN No. 4150) Tahun 2001. 
Selanjutnya Pasal 12 B Undang Undang Nomor. 31 Tahun 1999 Jo UndangUndang Nomor 20 Tahun 2001 Tentang Pemberantasan Tindak Pidana Korupsi menyebutkan, bahwa;

1. Setiap gratifikasi kepada pegawai negeri atau penylenggara negara dianggap pemberian suap, apabila berhubungan dengan jabatannya dan berlawanan dengan kewajiban atau tugasnya, dengan ketentaun sebagai berikut;

a. Yang nilainya Rp. 10.000.000., (sepuluh juta rupiah) atau lebih, pembuktian bahwa gratifikasi tersebut bukan merupakan suap dilakukan oleh penerima gratifikasi.

b. Yang nilainya kurang dari 10.000.000., (sepuluh juta rupiah) pembuktian bahwa gratifikasi tersebut suap dilakukan oleh penuntut umum.

2. Pidana bagi pegawai negeri atau penyelenggara negara sebagaimana dimaksud dalam ayat (1) adalah pidana penjara seumur hidup atau pidana penjara paling singkat 4 (empat) tahun dan paling lama 20 (dua puluh) tahun, dan pidana denda paling sedikit Rp. 200.000.000., (dua ratus juta rupiah) dan paling banyak Rp. 1.000.000.000., (satu miliar rupiah)

Secara logis, tidak mungkin dikatakan adanya suatu penyuapan apabila tidak ada pemberi suap dan penerima suap. Sedangkan adapun apa yang dimaksud dengan gratifikasi dijelaskan dalam penjelasan Pasal 12B ayat (1) UU Tipikor, sebagai berikut: Gratifikasi adalah pemberian dalam arti luas, yakni meliputi pemberian uang, barang, rabat (discount), komisi, pinjaman tanpa bunga, tiket perjalanan, fasilitas penginapan, perjalanan wisata, pengobatan cuma-cuma, dan fasilitas lainnya. Gratifikasi tersebut baik yang diterima di dalam negeri maupun di luar negeri dan yang dilakukan dengan menggunakan sarana elektronik atau tanpa sarana elektronik.

Lebih spesifik mengenai gratifikasi dapat dilihat pada Buku Saku " Memahami Gratifikasi" yang diterbitkan Komisi Pemberantasan Korupsi . Di dalam buku tersebut diuraikan contoh-contoh pemberian yang dapat dikategorikan sebagai gratifikasi ${ }^{39}$ yang sering terjadi, yaitu:

1. Pemberian hadiah atau parsel kepada pejabat pada saat hari raya keagamaan, oleh rekanan atau bawahannya.

2. Hadiah atau sumbangan pada saat perkawinan anak dari pejabat oleh rekanan kantor pejabat tersebut.

3. Pemberian tiket perjalanan kepada pejabat atau keluarganya untuk keperluan pribadi secara cuma-cuma.

4. Pemberian potongan harga khusus bagi pejabat untuk pembelian barang dari rekanan.

5. Pemberian biaya atau ongkos naik haji dari rekanan kepada pejabat.

6. Pemberian hadiah ulang tahun atau pada acara-acara pribadi lainnya dari rekanan.

7. Pemberian hadiah atau souvenir kepada pejabat pada saat kunjungan kerja.

8. Pemberian hadiah atau uang sebagai ucapan terima kasih karena telah dibantu.

\footnotetext{
${ }^{39}$ Komisi Pemberantasan Korupsi, Buku Saku Memahami Gratifikasi, http://upg.kpk.go.id. Februari 2010 , hlm. 19
} 
Akan tetapi, menurut Pasal 12C ayat (1) UU Tipikor, gratifikasi yang diterima oleh pegawai negeri atau penyelenggara negara tidak akan dianggap sebagai suap apabila penerima gratifikasi melaporkan kepada KPK. Pelaporan tersebut paling lambat adalah 30 hari sejak tanggal diterimanya gratifikasi (Pasal 12C ayat (2) UU Tipikor). Dengan demikian, ancaman pidana tidak hanya dikenakan kepada pelaku penerima gratifikasi saja, tetapi juga kepada pemberinya.

Jika melihat pakta Pasal 5, 11, 12 dan 12 B beserta penjelasannya seperti telah dikemukan, terlihat sangat jelas hubungan kepala desa dengan pasal-pasal tersebut tidak ada keterkaitan. Penerapan pasal-pasal tersebut terhadap kepala desa yang melanggar norma diatas tidak dapat diterapkan. Namun, pada paktanya Jaksa Penuntut Umum menuntut kepala desa dengan pasal 11 dan 12.

\section{KESIMPULAN}

Kedudukan kepala desa tidak dapat dikategorikan memiliki status hukum pegawai negeri sipil atau penyelenggara negara seperti dimaksud undang-undang nomor 31 tahun 1999 jo undang-undang nomor 20 tahun 2001 tentang pemberantasan tindak pidana korupsi.

Status hukum kepala desa yang ideal dalam hubungannya dengan undang-undang nomor 31 tahun 1999 jo undang-undang nomor 20 tahun 2001 tentang pemberantasan tindak pidana korupsi adalah sebagai penyelenggara negara.

\section{SARAN}

Undang-undang nomor 31 tahun 1999 jo undang-undang no 20 tahun 2001 tentang pemberantasan tindak pidana korupsi tidak menjelaskan kedudukan hukum kepala desa sebagai pegawai negeri sipil atau penyelenggara negara. Maka, untuk mempertegas kedudukan hukum kepala desa tersebut perlu dilakukan revisi atau perubahan.

Dalam revisi atau perubahan undang-undang nomor 31 tahun 1999 jo undang-undang nomor 20 tahun 2001 tentang pemberantasan tindak pidana korupsi perlu ditambah atau disisipkan satu ayat yang mengatur status kedudukan hukum kepala desa, yaitu sebagai penyelenggara negara.

\section{DAFTAR PUSTAKA}

\section{Buku}

Arianto, Satya, Hukum Dan Demokrasi, Jakarta : Pusat Studi Hukum Tata Negara, FHUI, 1991.

Anwar, Chairul. Konstitusi dan Kelembagaan Negara. Jakarta: CV. Novindo Pustaka Mandiri,1999.

Abdul Mukthie Fadjar, Tipe Negara Hukum. Malang: Bayumedia Publishing, 2005. 
,Negara Hukum Dan Perkembangan Teori Hukum, Sejarah Dan Pergeseran Paradigma. Malang: Intrans Publishing, 2018.

Azhary, Negara Hukum Indonesia Analisis Yuridis Normatif Tentang UnsurUnsurnya. Jakarta: UI-Press. 1995.

Bagir Manan dan Kuntana Magnar, Beberapa Masalah Hukum Tata Negara Indonesia, Bandung: Alumni. 1997.

Bahder Johan Nasution,Negara Hukum Dan Hak Asasi Manusia. Bandung: Mandar Maju. 2014.

Bintan R Saragih, Clean Government Dalam Rangka Mewujudkan Negara Hukum. Jakarta: Pidato Ilmiah UNTAG. 1994.

Budiharjo Miriam, Aneka Pemikiran Tentang Kekuasaan Dan Wibawa, Jakarta :Pustaka Sinar Harapan, 1984.

,Dasar-Dasar Ilmu Politik, Jakarta:Gramedia,1984.

,Masalah Kenegaraan ,Jakarta:Gramedia,1975.

Didi Nazmi Yunas, Konsepsi Negara Hukum. Padang: Angkasa Raya. 1992.

Daerwin Prinst, Pemberantasan Tindak Pidana Korupsi,Bandung; PT Citraditya Bahkti, 2001.

Eko Susilo Madyo dan Triyanto Bambang, Pedoman Pnulisan Karya Ilmiah,Semarang:Dehara Prize, 1995.

Hiariej, O.S. Eddy,Prinsip-Prinsip Hukum Pidana. Yogyakarta: Edisi Revisi.2015

Hukum Pidana. Tanggerang: Universitas Terbuka. 2016.

H. Harris Soche, Supermasi Hukum Dan prinsip Demokrasi Di Indonesia. Yogyakarta: Hanindita Offset.1985.

Jimly Asshiddiqie, Menuju Negara Hukum Yang Demokrasi. Jakarta: Bhuana Ilmu Populer. 2009.

Joko Sasmito, Penghantar Negara Hukum dan Ham. Malang: Setara Press. 2018.

Kusnardi Moh dan Ibrahim Harmaili, Pengantar Hukum Tata Negara Indonesia, cet ke-7, Jakarta : Pusat Studi Hukum Tata Negara Fakultas Hukum UI dan CV Sinar Baksi, 1988.

Kusnardi Moh, Sususnan Pembagian Kekuasaan Menurut Sistem UUD 1945, Jakarta : Gramedia, 1994.

Manan, Bagir, Menegakkan Hukum Suatu Pencarian. Jakarta: Asosiasi Advokat Indonesia. 2009.

Reza A.A. Wattimena, Melampaui Negara Hukum Klasik, Locke-RousseauHabermas. Yogyakarta: Kanisius. 2007.

Ridwan, Hukum Administrasi Negara. Depok: Raja Grafindo Persada. 2018.

Sudargo Gautama, Pengertian Tentang Negara Hukum. Bandung: Alumni.1955.

Soetidjo, Hubungan Pemerintahan Pusat dan Pemerintahan Daerah, Jakarta : Rineka Cipta. 1990 
Syaukani, Menatap Harapan Masa Depan Otonomi Daerah, Kaltim: Gerbang Dayaku. 2001.

Sadu Wasistionao, Dilema Efesiensi Birokrasi Daerah. Jatinangor : CLGI. 2003.

Siswanto Sunarno, Hukum Pemerintahan Daerah di Indonesia, Jakarta: Sinar Grafika. 2006.

Soemantri, Sri, Sistem dan Prosedur Konstitusi. Bandung: Alumni.2006.

Sarja, Negara Hukum teori dan Praktek. Yogyakarta: Thafa Media. 2016.

Sibuea. Hotma P. Asas Negara Hukum, Peraturan Kebijakan dan Asas-asas Umum Pemerintahan Yang Baik. Jakarta: Erlangga. 2010. , Ilmu Negara. Jakarta: Erlangga. 2014. , dan Dwi Seno Wijanarko, Dinamika Negara Hukum. Depok: Raja Grafindo Persada. 2020.

, dan Asmak ul Hisnah. Sendi-sendi Hukum Konstitusional, Problematika Wewenang Organ Negara Dalam Penetapan Kerugian Keuangan Negara Dalam Tindak Pidana Korupsi. Depok: Rajawali Pers. 2020.

Soerjono Soekanto, Faktor-faktor Yang Mempengaruhi Penegakan Hukum. Depok, Rajawali Pers. 2019.

Padmo Wahjono, Indonesia Negara Berdasarkan Hukum. Jakarta: Ghalia Indonesia. 1983.

Willy D.S. Voll, Negara Hukum Dalam Keadaan Pengecualian. Jakarta: Sinar Grafika. 2013.

Yuswalina, Hukum Administrasi Negara. Malang: Setara press. 2018.

\section{Peraturan Perundang-Undangan}

Republik Indonesia, Undang-Undang Dasar Negara Republik Indonesia Tahun 1945.

Republik Indonesia, Undang-Undang Nomor 1 Tahun 1957 Tentang Pokok-Pokok Pemerintahan Daerah. (LN No. 6 TLN 1143)

Republik Indonesia, Ketetapan Majelis Permusyawaratan Rakyat Republik Indonesia Nomor XI/MPR/1998 tentang Penyelengaraan Negara yang Bersih dan Bebas Korupsi, Kolusi dan Nepotisme.

Republik Indonesia, Undang-Undang Nomor 22 Tahun 1999 Tentang Pemerintahan Daerah. (LN. No. 60. TLN. No. 3839)

Republik Indonesia, Undang-undang Nomor 28 Tahun 1999 Tentang Penyelenggaraan Negara Yang Bersih Dan Bebas Dari Korupsi Kolusi Dan Nepotisme. (LN No. 75, TLN.3851)

Republik Indonesia, Undang-undang Nomor 31 Tahun 1999 Tentang Pemberantasan Tindak Pidana Korupsi. (LN No. 140. TLN No. 3874)

Republik Indonesia, Undang-Undang Nomor 20 Tahun 2001 Tentang Perubahan Atas Undang-Undang Nomor 31 Tahun 1999 Tentang Pemberantasan Tindak Pidana Korupsi. (LN. No. 134. TLN No. 4150) 
Republik Indonesia, Undang-Undang Nomor 32 Tahun 2004 Tentang Pemerintahan Daerah. (LN No. 125. TLN No. 4437)

Republik Indonesia, Undang-Undang Nomor 5 Tahun 2014 Tentang Aparatur Sipil Negara (LN No. 6. TLN No. 5494)

Republik Indonesia, Undang-Undang Nomor 6 Tahun 2014 Tentang Desa. (LN No. 7, TLN No. 5495)

Republik Indonesia, Undang-Undang Nomor 23 Tahum 2014 Tentang Pemerintahan Daerah., (LN No. 244, TLN No. 5587)

\section{Karya Ilmiah}

Bagir Manan, Fungsi dan Materi Peraturan Perundang-Undangan, Makalah disampaikan pada Penataran Dosen Pendidikan dan Latihan Kemahiran Hukum BKS-PTN Bidang Hukum Se-Wilayah Barat, Fakultas Hukum Lampung, Bandar Lampung, 1994

Bambang Yudoyono, Makalah Telaah Kritis Implementasi UU No. 22/1999: Upaya Mencegah Disintegrasi Bangsa, disampaikan pada Seminar dalam rangka Kongres ISMAHI. Bengkulu. 2000.

Pardjoko, Filosofi Otonomi Daerah Dikaitkan Dengan Pelaksanaan Undang-Undang Nomor 22 Tahun 1999 dan Undang-Undang Nomor 25 Tahun 1999, Makalah Falsafa Sains (PPS 702), Program Pasca Sarjana/S3. Institut Pertanian Bogor. 2002.

Samsul Bachri, Otonomi Daerah Dalam Prospektif Struktur dan Fungsi Struktur dan Fungsi Birokrasi Daerah, Makalah yang disajikan dalam Seminar Nasional Otda Dalam Prosfektif Indonesia Baru, Makassar. 1999.

\section{Jurnal Hukum}

Yongki Putut Angkianata, Perubahan Kewenangan Pemerintah Desa Di Indonesia,Universitas Brawijaya: Malang, 2015.

Arif Sumeru, Kedudukan Pejabat Kepala Desa Dalam Penyelenggaraan Pemerintahan Desa, Universitas Airlangga; Surabaya, JKMP (ISSN.2338445X), Vol.4, No, 1, Maret 2016.

Sakinah Nadir, Otonomi Daerah Dan Desentralisasi Desa Menuju Pemberdayaan Masyarakat Desa, Universitas Hasanuddin Makassar: Jurnal Politik Profetik Volume 1 Nomor 1 Tahun 2003

Sugiman, Pemerintah Desa, Universitas Suryadarma, Binamulia Hukum, Jakarta; Vol. 7 No. 1. Juli 2018.

Abdul Rauf Alauddin Said, Pembagian Kewenangan Pemerintah Pusat-Pemerintah Daerah Dalam Otonomi Seluas-Luasnya Menurut UUD 1945, Yogyakarta; Fiat Jusstisia Jurnal Hukum (ISSN 1978-5186) Vol,9 No.4 Oktober-Desember 2015. 


\section{Internet ;}

http://m.mediaindonesia.com.,BNP:473 Kades Telah Teseret Korupsi Dana Desa., Februari 2020.

https://putusan.3mahkamahagung.go.id., Direktorat Putusan Mahkamah Agung Republik Indonesia.

http://www.djkp.go.id.,Kebijakan Dana Desa Tahun 2021.

http://www.jogloabang.com., Undang-Undang Desa, Februari 2020.

http://indonesiabaik.id/infografis/Sipa-Sipa Saja-Yang-Termasuk-Asn

http://busnees-law.bunus.ac.id., Siapa Subjek Tindak Pidana Korupsi., Februari 2017.

http://www.hukumonline.com.,Sekali Lagi Pasal 2 dan Pasal 3 UU Tipikor, April 2016.

http://www.hukumonline.com., memahami Kembali Delik Formil Pada Pasal 2 Dan Pasal 3 UU Tipikor, Februari 2017.

\section{Kamus ;}

Kamus Besar Bahasa Indonesia., Medan : Bitra Indonesia, Medan. 2013. 